\title{
CFOs in E-BUSINESS: E-ARCHITECTS or FOOT-SOLDIERS?
}

\author{
David O'Donnell \\ Intellectual Capital Research Institute of Ireland, Ballyagran, Ireland \\ Nick Bontis \\ DeGroote Business School, McMaster University, Hamilton, Canada \\ Philip O'Regan \\ University of Limerick, Ireland \\ Tom Kennedy \\ University of Limerick, Ireland \\ Peter Cleary \\ University College Cork, Ireland \\ Ailish Hannigan \\ University of Limerick, Ireland
}

\begin{abstract}
Acknowledgements: We wish to acknowledge the sponsorship of CIMA (Chartered Institute of Management Accountants) for this research project and we are particularly grateful to the CFOs who agreed to participate in this study. We would also like to thank Carole Brooke at Lincoln, Pat Doody at Tralee, Lars Bo Henriksen at Aalborg and Sven Völpel at Harvard for valuable insights on earlier versions of this paper. We are also grateful to the reviewers and delegates at the $3^{\text {rd }}$ McMaster World Congress on e-Commerce in Hamilton, Canada; ECITE 2002 in Paris, France; $25^{\text {th }}$ EAA in Copenhagen, Denmark; and 2002 IAM in Waterford, Ireland.
\end{abstract}

Correspondence: Dr. Nick Bontis, Associate Professor of Strategy, DeGroote Business School, McMaster University, 1280 Main Street West, MGD \#207, Hamilton, Ontario, Canada L8S 4M4 Tel: (905) 525-9140 x23918 nick@bontis.com

Note: This paper has been accepted for publication in Knowledge and Process Management. 


\title{
CFOs in E-BUSINESS: E-ARCHITECTS or FOOT-SOLDIERS?
}

\begin{abstract}
Both the role of the CFO (chief financial officer) and the discipline of accounting can be viewed as being in transition due to developments in the e-Business world. One perspective suggests that CFOs are becoming "e-process architects" - an alternative suggests that the CFO role is becoming commoditised to "foot-soldier" status with other roles such as CIOs (chief information officers) and CTOs (chief technology officers) staking a claim to its traditional accounting space. In this paper we present some preliminary evidence relating to this e-architect/footsoldier question, and on levels of e-Business activity, based on data obtained from over 120 CFOs in the Irish ICT sector.
\end{abstract}

Key Words: Accounting; Chief financial officers (CFOs); e-Business; Irish ICT sector.

\section{Introduction}

From the "lost relevance" debate of the 1980s (Johnson and Kaplan, 1987) through the rise of ICT (information and communications technology) mediated e-Business in the 1990s both the role of the CFO (chief financial officer) and the discipline of accounting can be viewed as being in transition. There is as yet, however, little clarity in the literature on what specifically this emerging CFO role is, or where exactly the discipline of accounting is likely to be positioned in the corporate e-Business world.

One perspective suggests that CFOs are being asked to act as "process architects" for their organisations (Hoffman, 2001). This idea of "CFO as e-Biz Architect" was also the guiding theme at the 10th Annual Business Week Forum of Chief Financial Officers (Business Week CFO Forum, 2001). Deise and his colleagues (2000: 205) suggestion that "the role of the CFO is not just to be the architect of the up-front plan, but to be the navigator of the company's course as he or she executes that plan" is typical of leading consulting-oriented discourse in this area. This proposed CFO role focuses on internal processes that cut across different business functions in an attempt to ensure that customers, suppliers and other e-Business partners are linked together throughout the entire e-value chain. Morgan's (2001) elaboration on this emerging CFO role as "architect of the enterprise in the information age" (see Figure 1.) is illustrative here.

Figure 1. Architect of the Enterprise?

\section{Emerging CFO Role?}

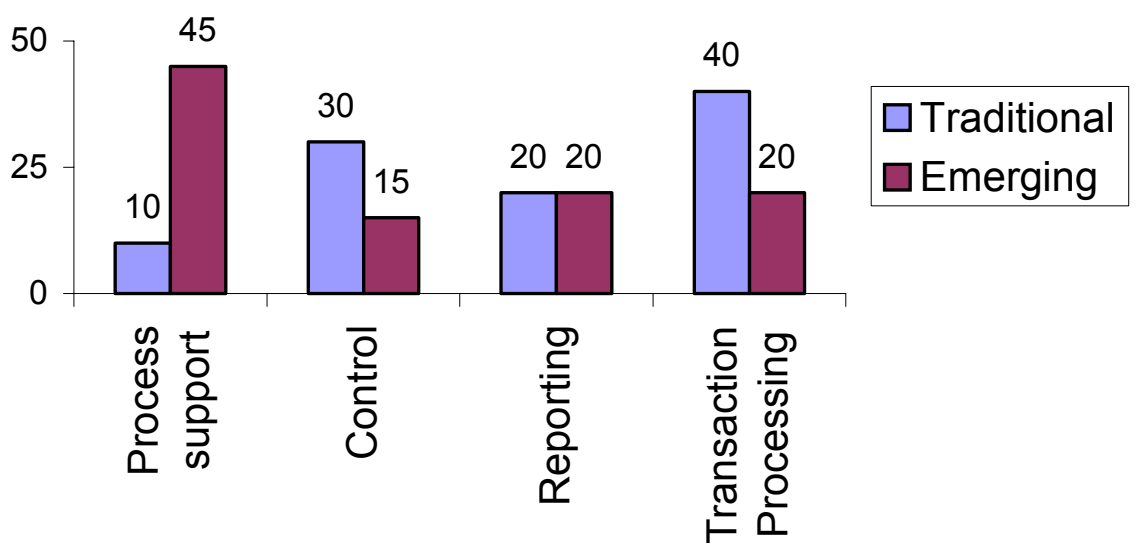

Source: Adapted from Morgan (2001) 
Morgan (2001) proposes a dramatic reduction in the time spent on transaction processing and control activities by CFOs due to developments in ICT enabled systems such as ERP (enterprise resource planning). With the time gained he suggests a concomitant increase in more strategic process support activities for CFOs such as establishing economic growth targets, portfolio investment priorities, strategic planning, EVA (economic value added) analysis and decision-making, and greater involvement in the development and monitoring of performance metrics and change management. Parker (2001: 438) suggests that the opportunities for information systems oriented accountants in e-Business are vast in areas such as:

....access to new markets and customers, closer links and new alliances with business partners and suppliers, improved communication, internal organisational process efficiencies and cost savings, improved supply chains, electronic procurement of inputs and supplies, electronic data interchange and electronic funds transfer.

From this glowing perspective, the CFO is becoming a central player in assessing, selecting, and implementing e-Business enabling infrastructure, technologies and processes; developing scaleable strategic partnerships; redesigning legacy business models; and creating a culture that is open to the rapid disruptive change that becoming an e-Business requires (Deise et al., 2000; EIU/Accenture, 2000; Hoffman, 2001; Parker, 2001; Morgan, 2001).

An alternative and starkly contrasting perspective, partly originating in the "lost relevance" debate (Johnson and Kaplan, 1987), suggests that accounting is becoming commoditised with a consequent downgrading of the CFO role to "foot-soldier" status. "Footsoldiers", according to Jack Prouty of KPMG, "make for bad e-Commerce executives" (Banham, 2001). The primary research question addressed here, based on data obtained from over 120 CFOs in the Irish ICT sector in mid 2001, is to ascertain where individual CFOs are positioned on this e-architect-foot-soldier continuum. A secondary focus is to gain some preliminary evidence on levels of e-Business activity within the Irish ICT sector itself.

The structure of the remainder of the paper is as follows. We first provide a brief review of recent research, with particular emphasis on the ICT sector. We then provide some background on the Irish context and on the research methodology employed. The findings on perceived levels of organisational implementation in six key e-Business areas and the personal level of involvement of CFOs in the implementation process are then presented. We tentatively conclude that although there is evidence of significant e-Business activity in this particular ICT sector and of CFO involvement, there remains quite some distance to be negotiated before either CFOs or their accounting functions can claim to be strategic leaders or e-architects in the eBusiness arena.

\section{From e-Business in General to CFOs in Particular}

There are few empirical studies and little theoretical clarity on what specifically this new CFO role is, or where exactly the discipline of accounting is strategically positioned in the emerging cross-functional and e-value chain based e-Business world (Ray et al., 2001; Sivabalan and Booth, 2001). CFOs are advised to automate transaction processes and leverage the time gained to substantially increase their process support activities (Deise et al., 2000; Morgan, 
2001). Control activities are further enabled by ERP systems, and a much broader focus on information, value, and market intelligence reporting is envisaged for the CFO. Bob Verheecke, CFO at CacheFlow Inc., claims that "It's the ability to turn data into real information, collecting it and distributing it to users so they can make decisions. In my role as CFO, I'm stepping further into that role of information architect" (Chabrow and Hayes, 2001). The implicit logic here is that CFOs who fail to take on this broader process support role, for whatever reason, risk being sidelined to foot-soldier status.

The comprehensive International Data Corporation (IDC) eWorld survey (Gantz, 2001) finds that large businesses are increasing their spending on e-Business by 20-30 per cent, and hoping to grow online revenue by up to 50 per cent. This study, conducted in the first half of 2001, obtained data from 13,000 CIOs and IT managers in 27 countries via telephone, and 2,000 online responses from Internet executives in 12 countries. This study demonstrates that eBusiness has passed through the transition from the Phase-1 "dotcom" era to Phase-2 "the infrastructure build-out" era, a finding broadly substantiated by the recent European Commission (2003) on e-Business.

According to the EIU/Accenture Report (2000a,b), however, many CFOs believe that their organisations lack the necessary structure and culture to account for e-Business effectively, and are struggling to redesign their finance functions and accounting methods. This study, conducted in 2000, obtained responses from CFOs in 276 major corporations in North America, Europe, and the Asia-Pacific region (EIU, 2000a; EIU/Accenture, 2000b; Enos, 2001). Daniel T. London notes that this particular survey indicates that many CFOs:

...doubt the ability of traditional metrics to evaluate key elements of operating in the new economy....e-commerce is changing the rules of the game and broadening the role of financial officers. New business models and innovative technologies are requiring greater levels of finance leadership to ensure long-term viability and success.....Transforming brick-and-mortar companies to ecommerce players requires CFOs to reassess their approach to capital investment and rates of return. They are being asked to evolve at e-speed and, in several instances, reorder their priorities. (Enos, 2001)

Almost two thirds of companies had had an e-Business strategy in place for two years or less, with almost 60 per cent stating that their e-Business strategy is reviewed on an ongoing rather than on an annual, basis. Echoing the continuing applicability of the "lost relevance" debate, only 17 per cent of CFOs believe that new revenue/cost streams can be accounted for "very effectively" by established processes - almost 60 per cent, however, continue to apply traditional evaluation techniques when considering capital investments. This survey confirms that, in most firms, the CEO is usually in charge of overseeing e-Business activities but that many CFOs serve on cross-functional senior teams. This top team structure offers CFOs direct participation in ongoing strategy formulation and such CFOs are certainly much more than mere foot-soldiers. This survey, however, suggests some disparity, especially in larger organisations, with respect to the perceived role of the CFO. Whereas CFOs view themselves as strategy facilitators, they are often viewed by senior management as primarily investment appraisers (EIU/Accenture, 2000a: 8). This report leans towards the "e-architect" end of the continuum in advocating the following strategic CFO actions: 
- Balance the customer value proposition with shareholder returns;

- Facilitate interactive corporate performance measurements;

- Web-enable the finance function with interactive, scalable solutions;

- Foster the entrepreneurial culture necessary to succeed in an e-Business world;

- Benchmark the state of readiness for e-Business against others in their industry;

- Implement performance measurements that react more quickly to the pressures of ecommerce;

- Prioritize technology initiatives that accelerate the speed of transaction processing and closing; and

- Provide the market intelligence necessary for more customer-driven enterprises.

Compared to these challenging imperatives, the present-day reality is probably somewhat different for most CFOs-Hoffman (2001) reports that many CFOs attending The 10th Annual Business Week Forum of Chief Financial Officers in the U.S. (February 28-March 2, 2001), especially in old economy organisations, continue to be "wary about braving the e-Business waters". In a poll of more than 100 attendees, 24 per cent of the respondents report that their companies were not involved in any kind of online business activity - even including such relatively mundane business functions as electronic invoicing.

Similar evidence is available in an Irish context. In the Deloitte-Touche/Enterprise Ireland (2000) survey of 200 CEOs in leading Irish businesses, 65 per cent of CEOs stated that eBusiness should be their responsibility. Marketing, however, at 43 per cent, emerged as the function most likely to be responsible for e-Business, ahead of finance at 39 per cent. Fifty eight per cent of CEOs claimed to have an e-Business strategy while 25 per cent were preparing an eBusiness strategy. The figures reported here for e-Business strategy, customer care, logistics/distribution and e-HR in the general Irish industrial population are, however, quite low.

Moving from the general to the more specific, the Deloitte/Touche survey of almost 100 CFOs in Irish companies (Finance, 2001) provides further evidence that there is significant distance yet to be negotiated in the journey if CFOs are to achieve e-architect status. Fifty four per cent of these CFOs stated that they did not understand the concept of ERP, 31 per cent did not understand many budgeting/reporting tools and 39 per cent stated that they had no real understanding of e-Business. Over a third were not satisfied with their financial systems and a "surprisingly large number" (Finance, 2001) did not understand concepts such as activity based costing (ABC), financial process redesign, value-based management and the balanced scorecard. In view of the research linking many of these activities to performance (Kennedy and AffleckGraves, 2001) the levels of understanding reported here are not particularly impressive.

In the foreword to a recent major European study on e-Business (European Commission, 2003: 5) Erkki Liikanen, the European Commissioner for Enterprise and the Information Society, notes that:

In order to reap the real benefits of investing in ICT, companies need to take further steps beyond simply 'going digital'. They need to improve both employers' and employees' skills, as well as to integrate ICT into their business processes. The focus has now to be shifted from basic connectivity and electronic commerce transactions to conducting business electronically. This emphasis on the productive use of ICT all along the value chain is reflected by the term 'eBusiness'. 
Further commenting on the findings of this seminal study, which we comment on below, he notes that:

...the remarkable differences observed sometimes at the national level, may have to be attributed to a large extent to the specificities of the particular economy and its structure....another lesson is that the full implementation of e-Business solutions is still in its infancy, in particular for most SMEs.

The main findings of the European Commission study on eBusiness, following the conceptual framework proposed by the OECD (Colecchia et al., 2000), are presented below in Table 1. European firms are making significant progress - which, in turn, is having a significant effect on how European firms operate.

Table 1. e-Business activity in Europe in 2002

\begin{tabular}{|c|c|c|c|}
\hline e-Readiness & e-Activity & e-Integration & e-Impacts \\
\hline $\begin{array}{c}\text { ICT infrastructure and } \\
\text { skills development }\end{array}$ & $\begin{array}{c}\text { e-Commerce (frequency } \\
\text { and intensity) }\end{array}$ & $\begin{array}{c}\text { Business processes } \\
\text { within and between firms }\end{array}$ & $\begin{array}{c}\text { Effects of e-Business } \\
\text { activities on firms }\end{array}$ \\
\hline $\begin{array}{l}\text { - } \text { Connectivity } \\
\text { - } \text { Bandwidth } \\
\text { - } \text { access } \\
\text { - } \text { Demand for IT staff } \\
\text { - } \text { Skills development } \\
\text { - } 94 \% \text { use computers } \\
\text { - } 83 \% \text { have access to } \\
\text { the internet, but } 28 \% \\
\text { of those still use a } \\
\text { dial-up modem to } \\
\text { connect } \\
\text { - } 71 \% \text { use the WWW } \\
\text { - } 29 \% \text { have a company } \\
\text { intranet } \\
\text { - } \text { About } 12 \% \text { of staff is } \\
\text { mainly occupied with } \\
\text { IT maintenance } \\
\text { - } 13 \% \text { searched for IT } \\
\text { staff in the past } 12 \\
\text { months } \\
\text { - } 3 \% \text { of employees } \\
\text { work in firms } \\
\text { supporting IT training } \\
\text { schemes }\end{array}$ & $\begin{array}{l}\text { - } 52 \% \text { have a web } \\
\text { presence } \\
\text { - } \quad 13 \% \text { make online } \\
\text { sales, } 42 \% \text { of those for } \\
\text { more than } 2 \text { years } \\
\text { - } \quad \text { Company website is } \\
\text { the main channel for } \\
\text { online sales }(85 \%) \\
\text { - } 70 \% \text { report that online } \\
\text { sales account for } \\
<10 \% \text { of total sales } \\
34 \% \text { make online } \\
\text { purchases } \\
62 \% \text { report that online } \\
\text { purchases account for } \\
<10 \% \text { of total } \\
\text { procurement } \\
5 \% \text { trade on B2B e- } \\
\text { marketplaces }\end{array}$ & 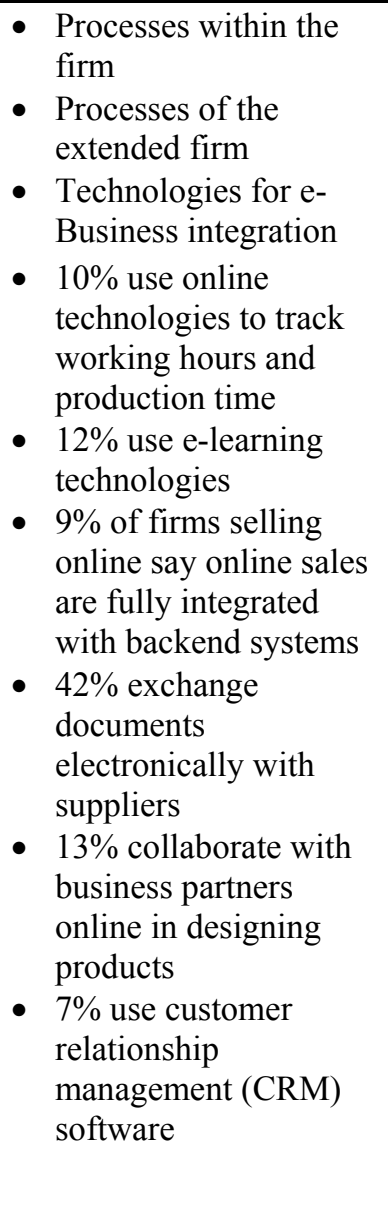 & $\begin{array}{l}\text { - } \text { Impacts of online } \\
\text { procurement and } \\
\text { selling } \\
\text { - } \text { Overall impacts } \\
\text { - } \text { Satisfaction } \\
\text { - } \text { Planned expenditures } \\
\text { - } 12 \% \text { say e-Business } \\
\text { constitutes a } \\
\text { significant part of how } \\
\text { they operate } \\
\text { - } 27 \% \text { of all businesses } \\
\text { say that e-Business has } \\
\text { changed their internal } \\
\text { work processes; } 24 \% \\
\text { customer relationships } \\
\text { - } 14 \% \text { are "very } \\
\text { satisfied" with their e- } \\
\text { Business activities; } \\
\text { 74\% "fairly satisfied" } \\
\text { - } 32 \% \text { planned to } \\
\text { increase their e- } \\
\text { Business expenditures } \\
\text { in } 2002-3 ; 60 \% \text { wanted } \\
\text { to maintain level } \\
\text { - } 45 \% \text { think that large } \\
\text { firms will mainly } \\
\text { benefit from e- } \\
\text { Business; } 35 \% \text { say } \\
\text { SMEs and large firms } \\
\text { will benefit equally }\end{array}$ \\
\hline
\end{tabular}

Source: Adapted from European Commission (March, 2003: 11) 
Firm size (Table 2) and sector are found to be the main differentiators, with the Electronics and ICT services sectors (Tables 3 \& 4) noted early adopters.

Table 2. Diffusion of sophisticated e-Business solutions by company size class (\% firms)

\begin{tabular}{|l|c|c|c|}
\hline \multirow{2}{*}{$\begin{array}{l}\text { e-Business } \\
\text { solution }\end{array}$} & \multicolumn{3}{|c|}{ Adoption rate by All firms (percentage) } \\
\cline { 2 - 4 } & $\begin{array}{c}\text { Small firms } \\
(0-49)\end{array}$ & $\begin{array}{c}\text { Medium firms } \\
(50-249)\end{array}$ & $\begin{array}{c}\text { Large firms } \\
(250+)\end{array}$ \\
\hline CRM & 7 & 13 & 31 \\
\hline SCM & 2 & 4 & 13 \\
\hline KM & 6 & 9 & 18 \\
\hline ERP & 6 & 21 & 38 \\
\hline
\end{tabular}

Source: adapted from European Commission (March, 2003: 29)

Table 3. ICT services: Current and planned usage of specific e-Business solutions

\begin{tabular}{|l|c|c|c|c|c|}
\hline \multirow{2}{*}{$\begin{array}{l}\text { e-Business } \\
\text { solution }\end{array}$} & $\begin{array}{c}\text { All } \\
\text { sectors }\end{array}$ & All ICT firms & $\begin{array}{c}\text { Small } \\
(0-49)\end{array}$ & $\begin{array}{c}\text { Medium } \\
(50-249)\end{array}$ & $\begin{array}{c}\text { Large } \\
(250+)\end{array}$ \\
\cline { 3 - 6 } & & 22 & 22 & 40 & 53 \\
\hline CRM & 2 & 3 & 3 & 4 & 12 \\
\hline KMM & 5 & 18 & 17 & 29 & 19 \\
\hline ERP & 7 & 8 & 8 & 37 & 51 \\
\hline e-Learning & 12 & 30 & 30 & 30 & 44 \\
\hline EDI & 9 & 12 & 12 & 27 & 40 \\
\hline Bayyyy & & & &
\end{tabular}

Base: EU-4 (D, F, I, UK), all firms. N=403 (for ICT services), $\mathrm{n}=5917$ (for all sectors)

CRM: Customer relationships management; SCM: Supply chain management; KM: Knowledge management; ERP: Enterprise resource planning; EDI: Electronic data interchange

Source: adapted from European Commission (March, 2003: 214)

Table 4. Perceived Impact of e-Business on firms in ICT services sector

\begin{tabular}{|l|c|c|c|c|c|}
\hline \multicolumn{1}{|c|}{$\begin{array}{c}\text { e-Business has } \\
\text { significantly } \\
\text { changed... }\end{array}$} & \multirow{2}{*}{$\begin{array}{c}\text { All } \\
\text { sectors }\end{array}$} & $\begin{array}{c}\text { All ICT } \\
\text { firms }\end{array}$ & $\begin{array}{c}\text { Small } \\
(0-49)\end{array}$ & $\begin{array}{c}\text { Medium } \\
(50-249)\end{array}$ & $\begin{array}{c}\text { Large } \\
(250+)\end{array}$ \\
\hline $\begin{array}{l}\text { Organisational } \\
\text { structure }\end{array}$ & 6 & 10 & 10 & 8 & 21 \\
\hline $\begin{array}{l}\text { Internal work } \\
\text { processes }\end{array}$ & 10 & 14 & 14 & 11 & 15 \\
\hline $\begin{array}{l}\text { Relationships to } \\
\text { customers }\end{array}$ & 8 & 13 & 13 & 11 & 13 \\
\hline $\begin{array}{l}\text { Relationships to } \\
\text { suppliers }\end{array}$ & 7 & 15 & 16 & 6 & 9 \\
\hline $\begin{array}{l}\text { Offers of products and } \\
\text { services }\end{array}$ & 7 & 13 & 13 & 21 & 29 \\
\hline $\begin{array}{l}\text { Way of conducting } \\
\text { business }\end{array}$ & 8 & 17 & 17 & 16 & 17 \\
\hline Base: EU-4 (D, F, I, UK), all firms. N=403 (for ICT services), $\mathrm{n}=5917$ (for all sectors) \\
\hline
\end{tabular}

Source: adapted from European Commission (March, 2003: 216) 
Of particular interest to management, particularly financial management should be the impact that adopting e-Business has on the business of doing business. Taking the ICT Services sector as one example, we note in particular the much higher adoption rates (Table 3 ) and the changes taking place in internal work processes and in ways of conducting business (Table 4).

In a very substantive contribution to research on e-Business adoption, Zhu, Kraemer and $\mathrm{Xu}$ (2002), based on their analysis of survey data from over 3,000 firms and more than 7,500 consumers in eight European countries (Germany, United Kingdom, Denmark, Ireland, France, Spain, Italy and Finland), find that:

(1) Technology competence, firm scope and size, consumer readiness, and competitive pressure are significant adoption drivers, while lack of trading partner readiness is a significant adoption inhibitor; (2) As (e-Business)-intensity increases, two environmental factors - consumer readiness and lack of trading partner readiness-become less important; (3) In high (e-Business)-intensity countries, e-Business is no longer a phenomenon dominated by large firms; as more and more firms engage in e-Business, network effect works to the advantage of small firms. (4) Firms are more cautious in adopting e-Business in high (eBusiness)-intensity countries, which seems to suggest that the more informed firms are less aggressive in adopting e-Business. (Zhu et al., 2002: 2)

We now turn our attention to the Irish ICT sector-a sector composed of both small indigenous Irish firms and multinational subsidiaries.

\section{Research Context and Methodology}

The Irish ICT sector, which accounts for almost one third of Irish exports and one sixth of Irish GDP (Lillington, 2002), is a suitable site for conducting e-Business research. Ireland is now the largest software exporter in the world, due mainly to the presence of most of the major global players. Employing over 100,000 people, it is, along with the pharma-chem sector, a leading driver of the high GDP growth rates experienced in Ireland in recent times. Further, the ICT sector has grown at 18 per cent per annum, double the impressive GDP rates, between 1993 and 2000. Indigenous Irish firms play a very significant role, employing over half of the 30,000 people working directly in software, for example, its fastest growing segment. These indigenous firms are fully integrated into the global network and their success appears to be due to targeting international niche markets.

Over 600 firms were identified by the research team as operating within the ICT sector in Ireland. It was decided to target those with at least 10 full-time employees, a criterion met by 503 firms. Of the 503 questionnaires posted in mid-June 2001, 200 responses were received from CFOs. Telephone and email follow up techniques were used to boost response rates. Of these, 77 CFOs indicated either that their firms did not meet the parameters (ICT hardware, software or services) or were unwilling to participate, leaving a total of 123 usable responses and an effective response rate of 24.5 per cent, which can be considered reasonable for this type of research. Of these, 90 relate to indigenous Irish firms with the other 33 represented multinational subsidiaries. 
Figure 2. e-Business Research items

\begin{tabular}{|c|c|c|}
\hline $\begin{array}{l}\text { E-BUSINESS: Please indicate with a number between } 1 \text { and } 7 \text { the extent to which } \\
\text { your organisation has implemented the following e-Business activities, and the } \\
\text { level of your personal involvement. } 1 \text { represents no activity and } 7 \text { represents full } \\
\text { implementation /involvement }\end{array}$ & $\begin{array}{c}\text { Level of } \\
\text { Organisational } \\
\text { Implementation }\end{array}$ & $\begin{array}{c}\text { Level of } \\
\text { Personal } \\
\text { Involvement }\end{array}$ \\
\hline $\begin{array}{l}\text { - e-Process Management to seamlessly manage business processes within and } \\
\text { across the extended enterprise } \\
\text { e-Information Management to cohesively manage vital business } \\
\text { information and leverage it for new opportunities. } \\
\text { e-Human Resource Management to attract, recruit, train, develop, monitor } \\
\text { and remunerate employees using } \boldsymbol{e} \text {-HR and } \boldsymbol{e} \text {-Learning systems. } \\
\text { - e-Infrastructure Management to keep the core e-Business infrastructure } \\
\text { up, running and secure while connecting customers, suppliers, partners and } \\
\text { employees. } \\
\text { e-Financial Management, the extent to which you use EDI, electronic } \\
\text { banking, billing and others to manage financial affairs through electronic } \\
\text { means. } \\
\text { e-Market Orientation, the extent to which (first) your organisation (and then } \\
\text { yourself) focuses on customers, competitors and market shifts in your } \\
\text { business sector. }\end{array}$ & & \\
\hline
\end{tabular}

As part of the research design we sought information on levels of organisational implementation of e-Business activities and the degree of involvement of CFOs in this process. There appears to be little specific empirical academic research published in this field. Following a review of the general literature (Bontis and De Castro, 2000; CIMAGlobal.com; EEAonline.org, IFAC.org; Lucking-Reiley and Spulber, 2000; Pellissier, 2000; and Willcocks et al. 1997), commercial web sites of leading e-Business vendors were also reviewed. Four key generic areas were initially identified - e-finance, e-information, e-infrastructure and e-processand following pilot and focus group discussions, two more, e-HR and e-market orientation, were added (see Figure 2.)

Average CFO age is 37 years; 83 per cent are male; and 95 per cent are of Irish nationality. Their average industrial experience is 9 years with an average of slightly less than 5 years specific in-firm experience. Educational/professional data is mixed-almost 80 per cent have at least a college degree level education, almost 40 per cent have post-graduate qualifications and slightly less than half report professional qualifications in accounting, finance or taxation. This latter figure is probably due to the fact that in small emerging indigenous companies either the CEO or other senior director is responsible for the finance portfolio. Almost 55 per cent of CFOs are board members, 28 per cent are founding members and 95 per cent consider themselves to be members of the top management team (TMT). The power position is slightly higher for indigenous CFOs - 60 per cent are board members and one third are founding members.

Turnover figures, in millions of Euros, are as follows: All firms (avg.= $€ 26$ million, std. dev. $=88, \mathrm{n}=84)$; Irish owned firms (avg. $=€ 12$ million, std. dev. $=57, \mathrm{n}=69$ ); Multinational subsidiaries (avg. $=€ 87$ million, std. dev. $=159, \mathrm{n}=15$ ). These firms report an overall 12 per cent growth in employment over $2000(\mathrm{n}=114)$. Average number of employees is 91 (std. dev. $=143, \mathrm{n}=114$. Indigenous Irish firms are smaller $(\mathrm{avg} .=53, \mathrm{std} \mathrm{dev}=72, \mathrm{n}=84)$ than the 
multinational subsidiaries (avg. $=198$, std. dev. $=220, n=30$ ). Most Irish firms here can be classified as SMEs (small to medium sized enterprises).

\section{Findings and Discussion}

This preliminary data analysis $(\mathrm{n}=123)$ was carried out using SPSS for Windows (Version 10). Data for levels of organisational implementation for the six e-Business activities is summarised in Table 5.

Table 5: Levels of Organisational Implementation

\begin{tabular}{|l|c|c|c|}
\hline $\begin{array}{c}\text { e-Business Activity: } \\
\text { Organisational Levels of } \\
\text { Implementation }\end{array}$ & $\mathrm{N}$ & Mean & $\begin{array}{c}\text { Std. } \\
\text { Dev. }\end{array}$ \\
\hline e-Process management & 116 & 3.8 & 1.80 \\
\hline e-Information management & 118 & 4.0 & 1.66 \\
\hline e-Human Resource management & 116 & $2.8^{*}$ & 1.76 \\
\hline e-Infrastructure management & 118 & 4.1 & 1.94 \\
\hline e-Financial management & 119 & 4.3 & 1.71 \\
\hline e-Market Orientation & 117 & 4.3 & 1.81 \\
\hline $\begin{array}{l}\text { Likert scale: 1 = None to 7 = Full Implementation } \\
\text { Difference between the means statistically significant }(\mathrm{P}<0.0001) \\
\text { *e-HR significantly different from all other activities }(\mathrm{P}<0.05)\end{array}$ \\
\hline
\end{tabular}

A repeated measures analysis of variance (ANOVA) was carried out to investigate if there was a significant difference between the mean levels of organisational implementation for each of the six e-Business activities. The difference between the means was statistically significant $(\mathrm{P}<0.0001)$. Contrasts were then used to investigate which means differed. The mean level of organisational implementation for e-human resource management (e-HR) was significantly different from all other e-Business activities $(\mathrm{P}<0.05)$.

This latter finding on e-HR, albeit the lowest level reported, probably represents an increase on the 12 per cent on e-HR in the more general Deloitte/Touche (2000) survey of Irish CEOs and the 12 per cent on e-learning reported in the Chambers of Commerce of Ireland (2001;2003) surveys of e-Business and e-Learning in Irish SMEs. e-Recruitment and perhaps some automation of administrative aspects of the HR function probably account for this level of implementation, and there is now significant evidence (European Commission, 2003) that elearning activity is increasing in this sector. These CFOs explicitly recognise the contribution of human capital (Bontis, 2001) in the creation of intellectual capital (Bontis and Fitz-enz, 2002) in this sector (see O'Donnell et al., 2003; O’Regan et al., 2001).

Data for levels of personal CFO Involvement in implementing the six e-Business activities is summarised in Table 6. A repeated measures analysis of variance (ANOVA) was carried out to investigate if there was a significant difference between the mean levels of personal involvement for each of the six activities. The difference between the means was statistically significant $(\mathrm{P}<0.0001)$. The mean for personal $\mathrm{CFO}$ involvement in e-financial management was significantly different from all other activities $(\mathrm{P}<0.05)$. Given that the sample 
were finance directors/controllers, accountants or high level directors, the high level of personal involvement in e-financial management should not be surprising here.

Table 6. Levels of CFO personal involvement.

\begin{tabular}{|l|c|c|c|}
\hline $\begin{array}{c}\text { e-Business Activity: } \\
\text { Level of CFO Involvement }\end{array}$ & $\mathrm{N}$ & Mean & $\begin{array}{c}\text { Std. } \\
\text { Dev. }\end{array}$ \\
\hline e-Process management & 113 & 3.2 & 1.91 \\
\hline e-Information management & 115 & 3.5 & 1.94 \\
\hline e-Human Resource management & 114 & 2.5 & 1.95 \\
\hline e-Infrastructure management & 115 & 3.0 & 1.90 \\
\hline e-Financial management & 117 & $4.6^{*}$ & 2.07 \\
\hline e-Market Orientation & 114 & 3.4 & 1.98 \\
\hline \begin{tabular}{l} 
Likert scale: 1 = None to 7 = Full Involvement \\
Difference between the means statistically significant $(\mathrm{P}<0.0001)$ \\
*e-Finance significantly different from all other levels $(\mathrm{P}<0.05)$ \\
\hline
\end{tabular}
\end{tabular}

We suggest that the difference between organisational level implementation and the level of $\mathrm{CFO}$ involvement provides some insight into the e-architect-foot-soldier question. eArchitects would be expected to report high involvement levels, probably in advance of the level of e-Business implementation at the level of the firm.

Figure 3. CFO Involvement and Organisational Implementation.

\section{CFO : e-Architect or Foot-soldier?}

\section{$\square$ Organisational Level of Implementation $\square$ CFO Level of Involvement}

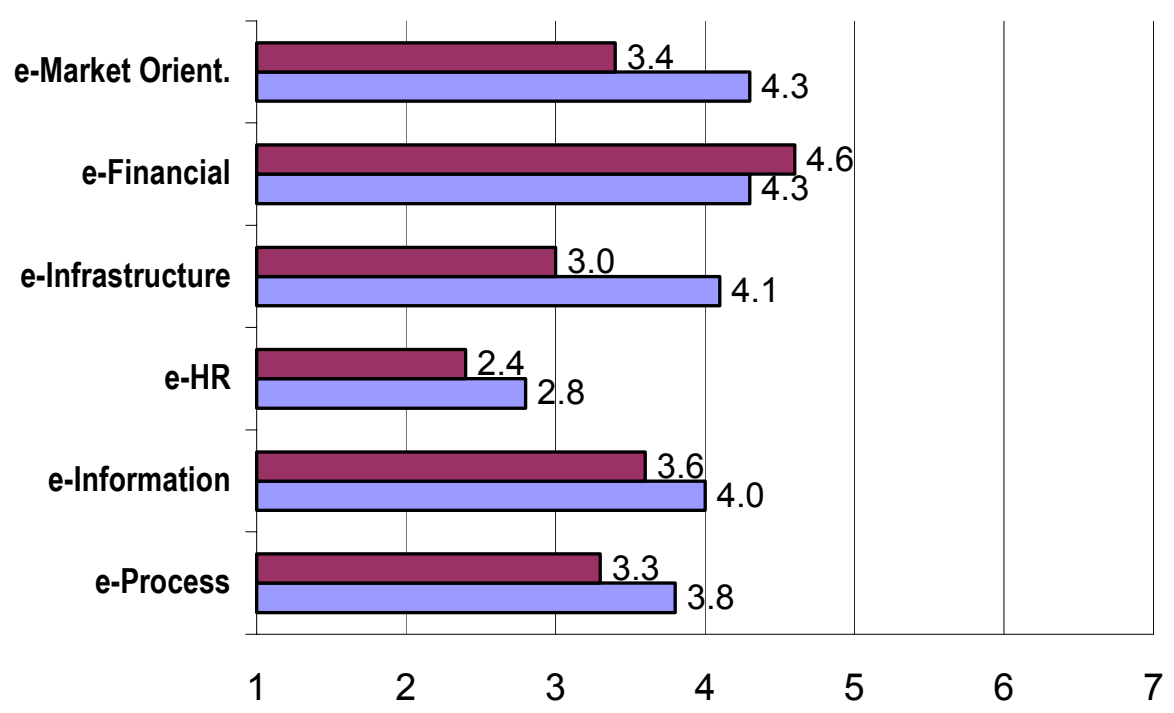


Figure 3 graphically illustrates the differences between the mean level of organisational implementation and personal CFO involvement in each of the six e-Business activities. Multiple paired t-tests were carried out to investigate if significant differences exist between the level of organisational implementation and personal CFO involvement for each of the six e-Business activities. After adjusting for multiple testing, the mean difference between the level of organisational implementation and CFO personal involvement was statistically significant for eprocess management, e-information management, e-infrastructure management and e-market orientation $(\mathrm{P}<0.05)$.

However, when the data is segmented and analysed by nationality of ownership, a different set of relationships emerge. For Irish companies $(n=90)$, only the mean difference between the level of organisational implementation and CFO personal involvement for einfrastructure management and e-market orientation was statistically significant $(\mathrm{P}<0.05)$. For multinational subsidiaries $(n=33)$, the mean difference between the level of organisational implementation and CFO personal involvement was statistically significant for e-process management, e-information management, e-human resource management, e-infrastructure management and e-market orientation $(\mathrm{P}<0.05)$. Segmented data is shown in Table 7 and an attempt is made in Figure 4 below to visually illustrate the contrasting perceptions of CFOs on implementation/involvement from the indigenous SME and multinational subsets of the data.

Table 7. Differences between Organisational levels of e-Business Implementation and CFO Involvement [Likert scale, 1-7]

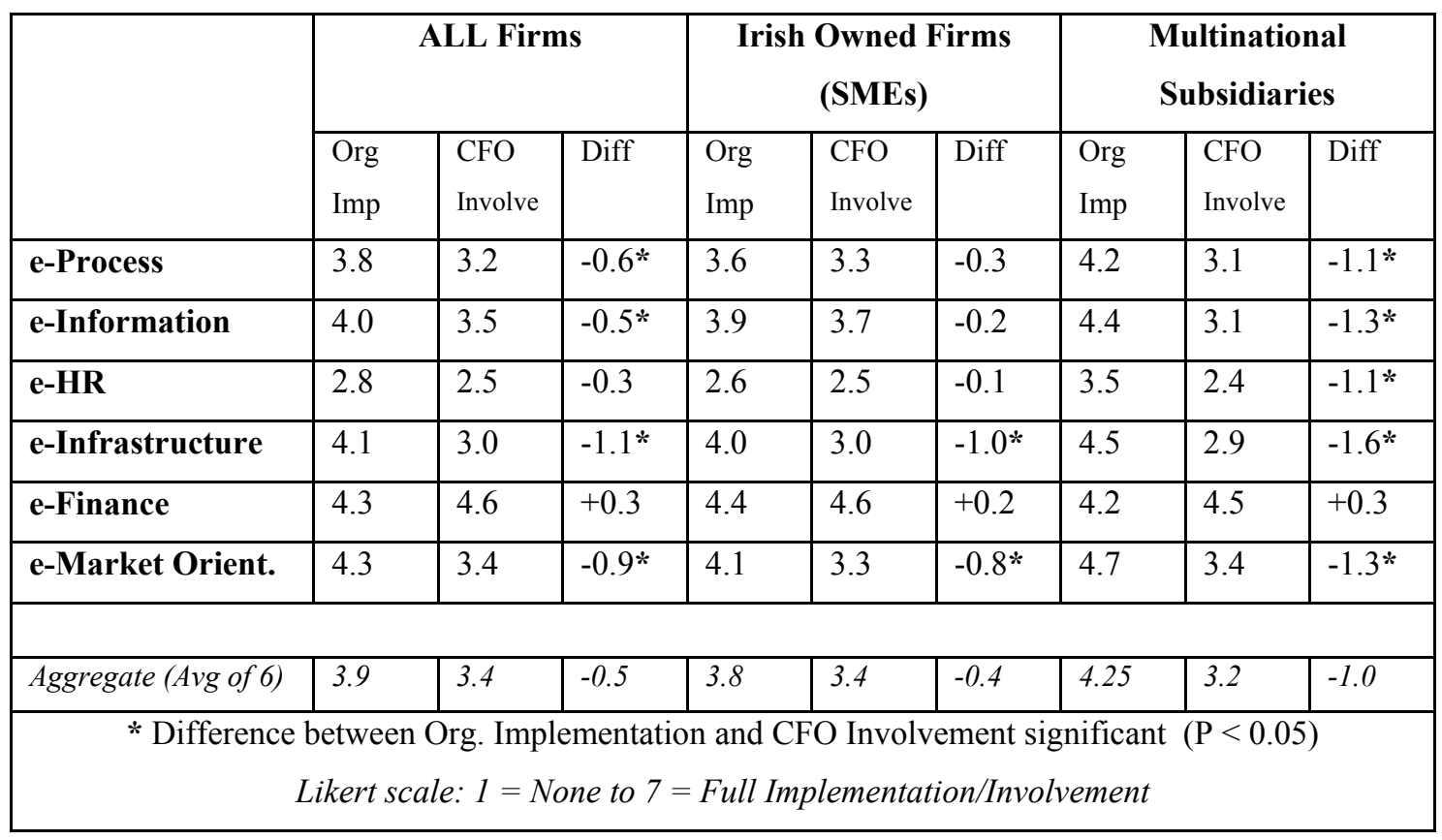

\section{Multivariate analysis}

Some exploratory multivariate analysis was undertaken to investigate the relationship between the outcome variables (mean rankings for the six e-Business activities) and the following explanatory variables: turnover, nationality $(1=$ Irish, $2=$ Multinational $)$, sector $(1=$ 
software, 2 = hardware, $3=$ services), age of the organisation, percentage of share capital that is Irish owned $(0-25,26-50 ; 51-75 ; 76-100)$, CFO membership of the top management team $(1=$ yes, $0=$ no), level of education of the CFO $(1=$ certificate, diploma or degree, $2=$ postgraduate, 3 = none), gender of the CFO $(1=$ male, 2 = female), accounting qualification of the CFO $(1=$ yes, $2=$ no), broad access to information in the firm ( 3 items), benchmarking ( 2 items), and the percentage of managers who undertake web-based training.

The first multivariate model investigated the relationship between the explanatory variables sector, nationality, share capital, age of organisation, turnover, access to information, benchmarking and the percentage of training on the Web and the outcome variables (mean rankings given for Organisational Implementation for the six e-Business areas). None of the variables were statistically significant predictors of the six e-Business outcomes.

The second model used an overall mean value for Organisational Implementation for the six e-Business areas as the outcome variable and the following explanatory variables - sector, nationality, age of organisation, turnover, access to information, benchmarking and the percentage of Web training. Turnover and the percentage of Web training were statistically significant predictors of the mean Organisational Implementation (Adjusted R squared $=18 \%$ ).

The third model used the mean value of CFO Involvement for the six e-Business areas as the outcome variable and the following explanatory variables-education, membership of the TMT, accounting qualification and gender. Only education was a statistically significant predictor (Adjusted R squared $=4 \%$ ).

Figure 4. Differences between Org. Implementation and CFO Involvement.

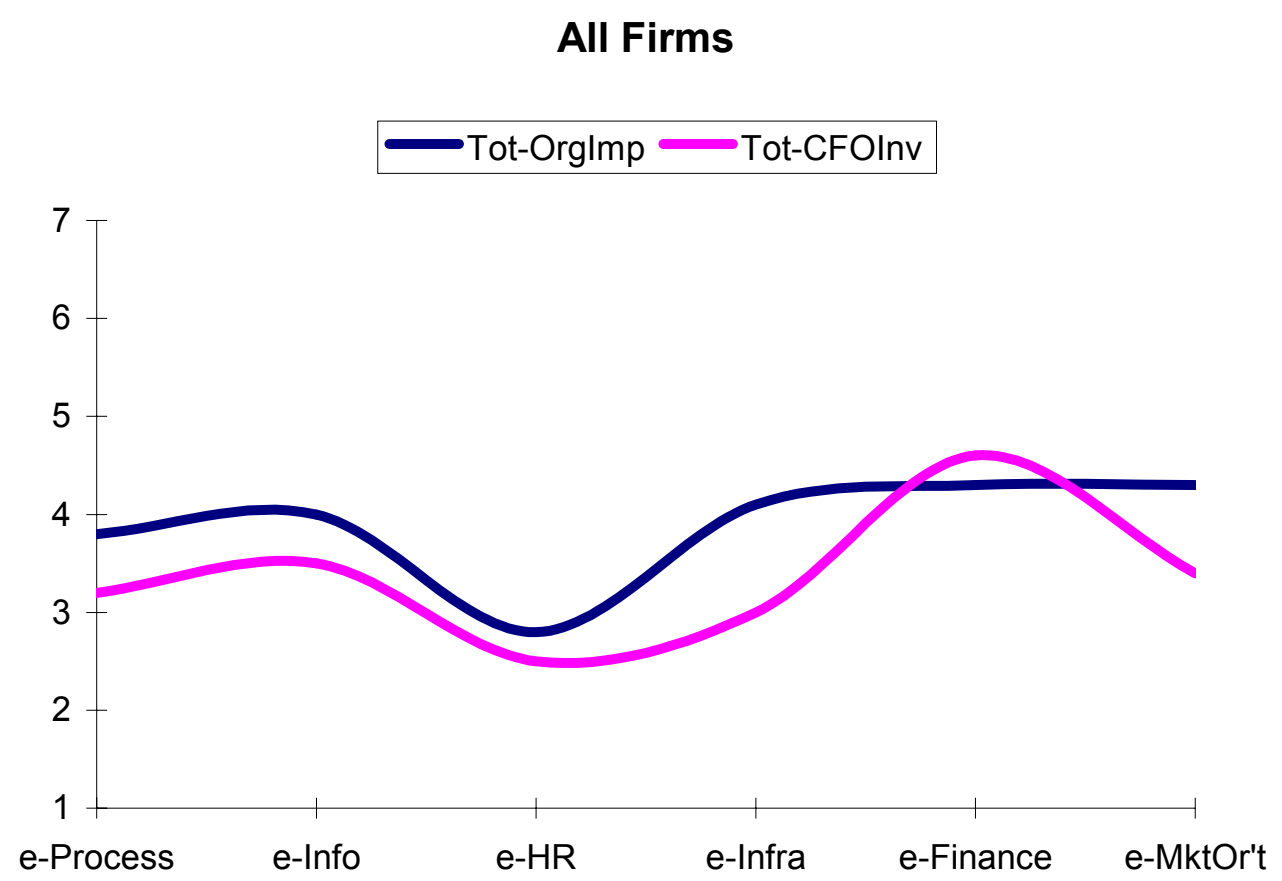




\section{Irish Owned Firms}

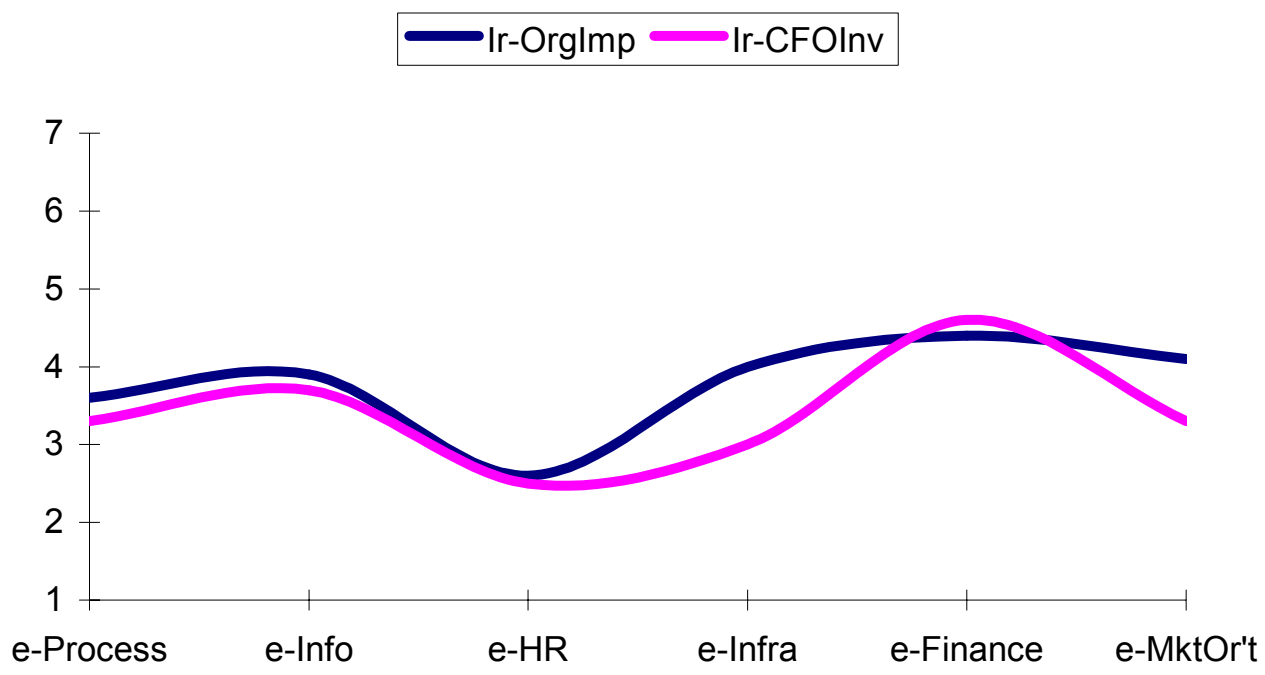

\section{Multinational Subsidiaries}
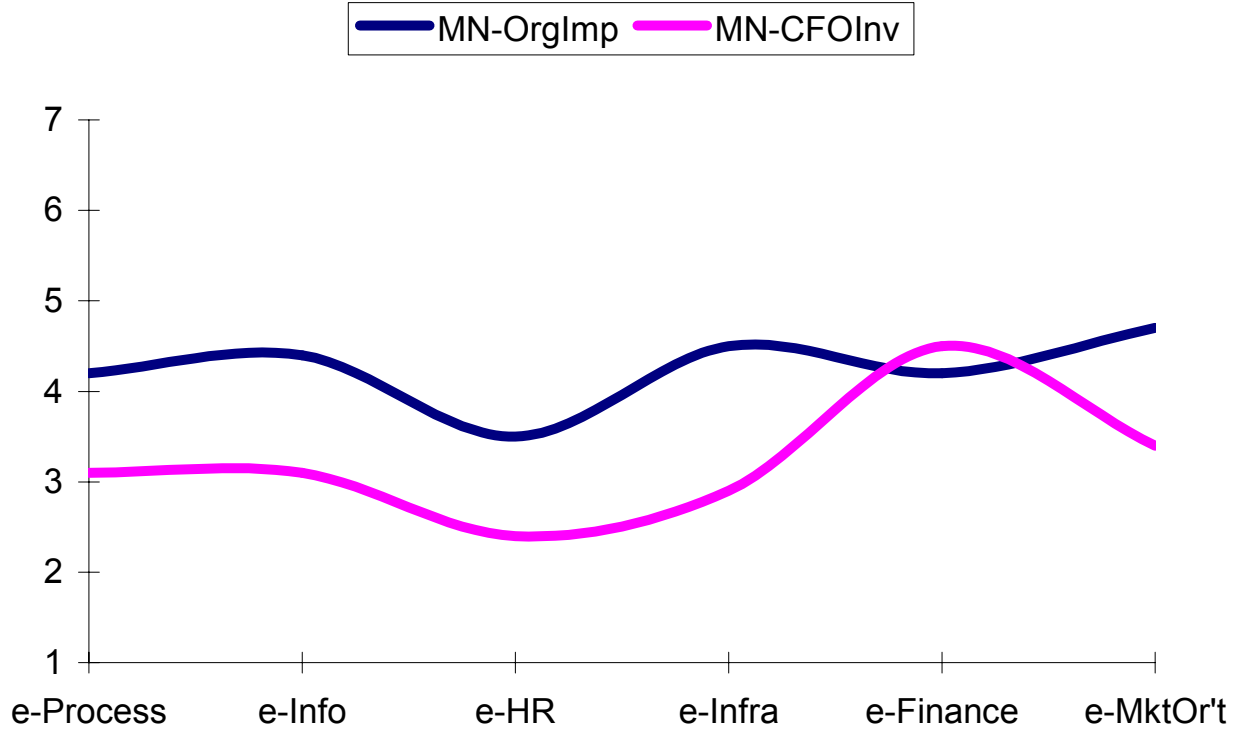

The final exploratory model used the mean value of the difference between Organisational Implementation and CFO Involvement for the six e-Business areas as the outcome variable and the following explanatory variables - education, nationality, turnover, age of the organisation, access to information and percentage of training on the web. Only turnover was a statistically significant predictor (Adjusted $\mathrm{R}$ squared $=15 \%$ ).

As nationality of ownership was not significant in the first model, and as turnover is really the only significant predictor identified above, we have to qualify discussion of multinational versus Irish owned firms as we cannot definitively isolate nationality and size effects at this stage. As noted above, turnover in multinational subsidiaries for which we have 
data is much greater than in Irish owned SMEs. We must, therefore, emphasise the exploratory nature of these general findings. None of the models explain much variation in the outcome variables with $\mathrm{R}$ squared values ranging from 4 to 18 per cent. Notwithstanding these qualifications, and the usual limitations inherent in cross-sectional survey design, we tentatively suggest the following:

The research design utilised here appears to be capable of producing relevant general findings with respect to the two areas of interest: levels of e-Business implementation and levels of CFO involvement in the process of implementing such activities [Differences between the means statistically significant for both Organisational and CFO levels $(\mathrm{P}<0.0001)$; Range 2.4 to 4.7; 1-7 Likert scale].

The levels of e-Business activity reported in the Irish ICT sector are not insubstantial. In terms of an e-Business ideal (7), the overall sector is perceived to be almost half-way there (Agg. 3.9). Multinational subsidiaries (Agg. 4.25) are somewhat further along than indigenous Irish firms (Agg. 3.8), their implementation levels exceeding the Irish on all (excepting e-Finance!) areas. Size effects, as noted in the European Commission report (2003), are apparent here. However, as Zhu and his colleagues (2002) argue, perhaps e-Business is no longer a phenomenon dominated by large firms in e-Business-intensive countries such as Ireland; as more and more firms engage in e-Business (and these small Irish ICT firms are export and globally oriented from day one of their existence) then network effects may be working to the advantage of the smaller indigenous firms.

In terms of CFO involvement in e-Business implementation a main finding is that CFOs are at least keeping up with, if perhaps not moving very far ahead of, the game in e-finance. The mean for personal CFO involvement in e-financial management is significantly different from all other activities $(\mathrm{P}<0.05)$, but the differences between implementation/involvement are not found to be statistically significant at any of the three levels of analysis.

In terms of CFO involvement in e-Business implementation in the other areas, however, the main finding is that $\mathrm{CFO}$ involvement lags the level of organisational implementation in all areas selected, excepting e-finance as noted above. This finding holds at the aggregate $(-0.50)$, multinational (-1.0) and Irish owned (-0.4) levels of analysis.

However, CFOs in the multinational subsidiaries appear to be less involved than their counterparts in the much smaller Irish firms. Excepting e-finance, this difference is significant (P $<0.05$ ) for all five e-Business activities in multinationals, but for only e-infrastructure and emarket orientation in Irish owned firms, the two e-Business areas where this difference is statistically significant at all three levels of analysis. In terms of e-infrastructure we can suggest that the highly technical aspects of this area is the domain of the CTO (chief technical officer). We suggest that is the area where CFOs are probably least likely to act as e-architects, and perhaps more so in multinational subsidiaries (-1.6). On e-market orientation there is no evidence here that CFOs are providing the market intelligence necessary for more customerdriven enterprises as suggested in the EIU/Accenture Report (2000a,b), although the organisational level of implemenatation in this area for multinationals (4.7) in the highest metric recorded. Market orientation refers to how an organisation gathers, disseminates and responds to market intelligence. Various authors have found a positive correlation between the market orientation of the organisation and various measures of success, such as ROI, sales growth and successful new product development (see Venter et al., 2001).

Our findings suggest that CFOs in small indigenous high growth firms need to be perhaps more e-Business savvy and become more rounded in this area, particularly in e-process and e- 
information. In small firms this may be because, as one Irish CFO in an Irish software firm commented during the pilot phase related to e-finance- "They have to!". Such CFOs do not have access to the global, and probably centralised, e-value chain expertise that exists within multinational corporations. This suggests one reason the levels of CFO involvement in multinational subsidiaries are significantly lower is that such decisions may be taken at corporate headquarters, with the e-Business solutions perhaps even implemented virtually by centralised coordinating units at corporate level. Or, as the multivariate analysis presented above suggests, we may simply be dealing with size (Turnover) effects, the one variable in the history of structural contingency theory that has stood the test of time, and which is strongly supported in the European Commission study, and tentatively here.

It would be difficult to classify these CFOs as foot-soldiers based on the levels of involvement reported. On the other hand, if CFOs were acting as the leading e-architects of eBusiness strategy in these organisations we might expect to see the involvement levels reported being in advance of the organisational levels of implementation. This is only the case in efinance and is not statistically significant at any of the three levels of analysis. Some broadening of the traditional CFO role as suggested by Deise et al. (2000), Morgan (2001), Parker (2001) and by the EIU/Accenture report (2000) is supported here, especially in small Irish owned firms, but whether this extends beyond investment appraisal or otherwise cannot be conclusively established at this stage.

Rather than focusing on the harsh dualism of an e-architect/foot-soldier continuum, perhaps current practice reflects the "evolutionary" approach documented by Bromwich and Bhimani (1989) and further developed in their monograph Management accounting: Pathways to progress (1994). Coltman and his colleagues (2000: 3 ) also argue for an evolutionary perspective in this area noting that "e-Business has not suspended the laws of economics...(and)...that it is premature to categorise e-Business as revolutionary." We concur. We have not even started here to touch on the complex set of relationships between actions, routines and institutions that may shape the process of change in this area (Brooke, 2001; Burns and Scapens, 2000; Di Maggio et al., 2001; Fountain, 2001; O'Donnell and Henriksen, 2002; Pellissier, 2000; Puxty, 1993; Zhou et al., 2002). Neoinstitutionalist theory (Dimaggio \& Powell, 1983; Meyer \& Rowan, 1977;), to take one example, would suggest that existing organisational arrangements and power networks mediate the enactment of new e-Business technologies and processes (Fountain, 2001) and further that CFOs would be expected to influence such enactments in an attempt to at least maintain, if not increase, their power positions within organisational hierarchies. More in-depth case studies are required before we can unpack some of the preliminary findings on the changing nature and scope of the $\mathrm{CFO}$ role indicated here.

A recent IFAC (2002) report suggests that the CFO in the year 2010 will have a very different world of technology to deal with and the key issue will not be how to use it, but how to ensure that it fits and is integrated to the best effect right across the e-value chain. "Beyond the reporting side," according to Heinz-Joachim Neubürger, Head of Corporate Finance and CFO of Siemens AG, "looms the whole concept of e-Business. CFOs will have to have a single set of set-ups to build the infrastructure required by e-Business, ensuring that we have a consistent set of ERP/SAP installations, for example. Providing the infrastructure for e-Business beyond CRM, logistics, etc, is going to be a tremendous challenge for CFOs" (IFAC, 2002: 16). 


\section{Conclusion}

In the introduction we noted that both the role of the CFO and the discipline of accounting can be viewed as being in transition. One perspective suggests that CFOs are becoming "e-process architects"- - with the alternative perspective suggesting that the CFO role is becoming commoditised to "foot-soldier" status with others such as CIOs and CTOs staking their claims to its traditional space. Two research questions were addressed here; firstly, to gain some insight into the positioning of CFOs on the e-architect-foot-soldier continuum, the main focus of this paper; and secondly, to gain some preliminary evidence into the levels of eBusiness activity in the Irish ICT sector.

The levels of e-Business activity reported here in the Irish ICT sector are not insubstantial. For most CFOs and their firms, however, there appears to be some distance yet to travel before "frictionless" (Brynjolfsson and Smith, 1999) e-Business becomes a realityalthough some progress is definitely evident here. With the exception of e-finance, the level of CFO involvement in the other five e-Business activities, however, lags the level of organisational implementation. The mean difference between the level of organisational implementation and CFO involvement is statistically significant for e-process management, e-information management, e-HR management, e-infrastructure management and e-market orientation for multinational subsidiaries; but is statistically significant only for e-infrastructure management and e-market orientation for small Irish owned firms, suggesting a broadening of the CFO role in small fast growing ICT firms that demands certain levels of e-Business expertise. Turnover/size is found to be the only significant predictor of mean organisational implementation and also of the mean difference between organisational implementation and CFO involvement.

As the Business Week CFO Forum (2001) noted, there is unquestionably considerable scope for enlarging the CFO's concept of e-Business: from simply a tool for cost reduction and efficiency enhancement to an opportunity for business model redesign, precision supply-and demand-chain management, and real-time gathering and reporting of strategic information. This perceived broadening of responsibilities makes the future of the CFO position far from clear. Some observers suggest that conflict is inevitable as CFOs, CIOs, CTOs and others vie for influence and power in the e-Business arena-others envision a day when the CIO's responsibilities will be absorbed into those of the CFO - or vice versa. Either way, the complex evolving role of the CFO exemplifies the cross-functional intertwining of business strategy, finance, information and communications technology, HR and e-Business. 


\section{REFERENCES:}

Banham, R. 2001. 'The new you: Putting a digital spin on an old economy company is no easy task', http://www.cfoeurope.com/ecfo0701a.html

Bontis, N. 2001. “Assessing Knowledge Assets: A review of the models used to measure intellectual capital”, International Journal of Management Reviews, 3(1): 41-60.

Bontis, N. and De Castro, A. 2000. 'The first world congress on the management of electronic commerce: review and commentary', Journal of Internet Research, 10(5): 365-373.

Bontis, N. and Fitz-enz, J. 2002. "Intellectual Capital ROI: A causal map of human capital antecedents and consequents", Journal of Intellectual Capital, 3(3): 223-247.

Bromwich, M. and Bhimani, A. 1989. Management Accounting: Evolution not Revolution, Chartered Institute of Management Accountants: London.

Bromwich, M. and Bhimani, A. 1994. Management Accounting: Pathways to Progress, Chartered Institute of Management Accountants: London.

Brooke, C. 2001. 'Information systems in use: A representational perspective', Tamara, 1(3): 3952.

Brynjolfsson, E. and Smith, M. 1999. 'Frictionless commerce? A comparison of internet and conventional retailers', e-Commerce Research Forum, MIT, http://ecommerce.mit.edu/cgi-bin/viewallpapers

Burns, J. and Scapens, R. W. 2000. 'Conceptualizing management accounting change: an institutional framework', Management Accounting Research, 11: 3-25.

Business Week CFO Forum 2001. 'CFO as eBiz Architect', http://conferences.businessweek.com/2001/cfo

Chabrow, E. and Hayes, M. 2001. 'Is the CFO a tech-savvy numbers cruncher or a fiscally savvy technology manager? It's something you need to know', http://www.informationweek.com/story/IWK20010614S0025

Chambers of Commerce of Ireland 2001. SME E-Business Survey 2001, CCI, Dublin, http://www.chambersireland.ie

Chambers of Commerce of Ireland 2003. E-Learning Report 2003, CCI/MORI, Dublin, http://www.chambersireland.ie

CIMA 2000-3. Chartered Institute of Management Accountants, www.cimaglobal.com

Colecchia, A., Pattinson, B. and Atrostic, B. K. 2000. 'Defining and measuring Electronic Commerce: A discussion paper'. OECD, Paris, February.

Coltman, T., Devinney, T. M., Latukefu, A. and Midgley, D. F. 2000. 'E-Business: Revolution, Evolution or Hype?' INSEAD Working Paper Series

Cronk, M. and Fry, G. 2001. 'IT evaluation: how far have we come?' Southern African Business Review, 5(1).

Deise, M. V., Nowikow, C., King, P. and Wright, A. 2000. Executive's Guide to E-Business: From Tactics to Strategy, PricewaterhouseCoopers/John Wiley: New York. 
Deloitte \& Touche/Enterprise Ireland 2000. 'Management Briefing: Survey-Chief Executives 2000', Deloitte \& Touche, Dublin, http://www.deloitte.ie

DiMaggio, P., Hargittai, E., Neuman, W. R. and Robinson, J. P. 2001. 'Social implications of the Internet', Annual Review of Sociology, 27: 307-336.

DiMaggio, P.J. and Powell, W. W. 1983. 'The iron cage revisited: Institutional isomorphism and collective rationality in organizational fields', American Sociological Review, 48:147-160

EIU/Accenture 2000a. 'Executive Briefing - E-commerce and the CFO: A framework for finance in the new economy', The Economist Intelligence Unit in co-operation with Accenture, EIU: New York.

EIU/Accenture 2000b. E-Commerce and the CFO: A framework for finance in the new economy. Economist Intelligence Unit (EIU)/Accenture, http://store.eiu.com

Enos, L. 2001. 'One Year Ago: Study - CFOs Not Ready for E-Commerce', E-Commerce Times, July 27, http://www.ecommercetimes.com/perl/story/12022.html

European Commission. 2002. Synthesis report: e-Business and ICT skills in Europe, European Commission, Luxemburg, June.

European Commission. 2003. The European e-Business report 2002/2003-A portrait of eBusiness in 15 sectors of the EU economy. $1^{\text {st }}$ Synthesis Report of the e-Business W@tch, European Commission, Luxemburg, March.

Finance. 2001. 'CFOs in the dark about ERP, Finance, 15(6): 3. June.

Fountain, J. E. 2001. Building the virtual state: Information, technology and institutional change, Brookings Institution: Washington, DC.

Gantz, J. 2001. 'eWorld 2001 Perception versus reality', IDC White Paper, IDC: Framingham, MA. http://www.idc.com/ITOver/eworld.htm

Hoffman, T. 2001. 'CFOs on e-Business: Not so fast', http://www.computerworld.com/cwi/story/0,1199,NAV47_STO58211,00.html

IFAC .2002. The role of the chief financial officer in 2010, January, http://www.ifac.org/Members/Download.tmpl?PubID=101043580579196

IFAC. 2001. International Federation of Accountants, http://www.ifac.org

Johnson, H.T. and Kaplan, R. S. 1987. Relevance Lost: The Rise and Fall of Management Accounting, Harvard Business School Press: Boston, MA.

Kennedy, T. and Affleck-Graves, J. 2001. 'The impact of Activity-Based Costing techniques on firm performance', Journal of Management Accounting Research, 13: 19-45.

Lillington, K. 2002. 'ICT sector rides out storm', The Irish Times, Business this Week, p.9, March $1^{\text {st }}$.

Lucking-Reiley, D. and Spulber, D. F. 2000. 'Business-to-Business Electronic Commerce', eCommerce Research Forum, MIT, November 1 version, http://e-commerce.mit.edu/cgi$\mathrm{bin} /$ viewallpapers

Meyer, J. W. and Rowan, B. 1997. 'Institutionalized organizations: Formal structure as myth and ceremony', American Journal of Sociology, 83: 340-363. 
Morgan, M. J. 2001. 'A new role for finance: Architect of the enterprise in the information age', Strategic Finance, August, http:/www.mamag.com/strategicfinance/2001/08h.htm

O’Donnell, D. and Henriksen, L. B. 2002. 'Philosophical foundations for a critical evaluation of the social impact of ICT', Journal of Information Technology, 17(2), 89-99.

O’Donnell, D., O’Regan, P., Coates, B., Kennedy, T., Keary, B. and Berkery, G. 2003. 'Human interaction: The critical source of intangible value', Journal of Intellectual Capital, 4(1): 82-99.

O'Regan, P., O’Donnell, D., Kennedy, T., Bontis, N. and Cleary, P. 2001. 'Perceptions of Intellectual Capital: Irish Evidence', Journal of Human Resource Costing and Accounting, 6(2): 29-38.

Parker, L. D. 2001. 'Back to the future: The broadening accounting trajectory', British Accounting Review, 33: 421-453.

Pellissier, R. 2000. 'Information technology - Future perfect?', Southern African Business Review, 4(1): 66-79.

Puxty, A. G. 1993. The social and organizational context of management accounting, Academic Press: London.

Ray, A. W., Cohen, E. E., Horton, T., Le Grand, C. and Ramamoorti, S. 2001. 'Applied research opportunities in the information age', Presented at AAA-IS Mid-year Conference, United States.

Sivabalan, P. and Booth, P. 2001. 'The impact of management accounting information systems on e-Business: An exploratory study', Working Paper No. 48, School of Accounting, University of Technology, Sydney, November.

Venter, P., Pellissier, R. and Strydom, J. 2001. 'Towards bridging the marketing information gap: An overview', Southern African Business Review, 5(2)

Willcocks, L., Feeny, D. and Islei, G. (Eds.), 1997. Managing IT as a Strategic Resource, London: McGraw-Hill.

Zhu, K., Kraemer, K. L. and Xa, S. 2002. A cross-country study of electronic business adoption using the technology-organisation-environment framework. Center for Research on Information Technology and Organizations (CRITO), http://crito.uci.edu/publications/pdf/CrossCountryStudy.pdf 